\title{
The Impact of Sponsorship Awareness in Low Involvement Settings
}

\author{
Frances M Woodside \\ University of Southern Queensland \\ E-Mail:woodside@usq.edu.au \\ Jane Summers \\ University of Southern Queensland \\ E-Mail: summersj@usq.edu.au
}

\begin{abstract}
The rapid growth of corporate sponsorship (USD $\$ 44$ billion worldwide), has led to the emergence of 'sponsorship clutter.' As a large proportion of companies that are involved with sponsorship have a primary objective of increasing brand awareness, it has become increasingly important to determine how awareness influences consumer responses to sponsorship. However, despite a breadth of understanding surrounding sponsorship and how it impacts consumer behavior, few studies have considered sponsorship from a packaging perspective; particularly in low involvement settings. Using structural equation modeling, this research empirically investigated the relationship between awareness of sponsorship arrangements and consumer response to sponsorship packaging. Results indicate that while leveraging sponsorship on grocery packaging positively impacts consumer responses toward the brand, prior awareness appears to have little impact on this response. Further, awareness of the sponsorship arrangement moderates the relationship between the perceived fit of the arrangement and a consumer's response to the sponsorship packaging. That is, for consumers who are not yet aware of a sponsorship arrangement, perceived fit plays a greater part in consumer response. The understanding offered in this paper has strategic relevance for brand managers in guiding sponsorship and package design decisions.
\end{abstract}

Keywords: Sponsorship, Packaging, Low Involvement, Awareness, Grocery, IMC 


\section{INTRODUCTION}

With large corporations, such as Coca-Cola, allocating over USD \$230 million to sponsorship (IEG, 2007), this activity has become a critical strategic tool with the potential to generate a sustainable competitive advantage in the marketplace. However, the rapid growth of corporate sponsorship in recent decades, (now reaching USD $\$ 44$ billion worldwide) (Chipps, 2010), has led to a cluttered marketplace for sponsorship. Events and properties may have a large number of official sponsors, which limits the value of this marketing tool for potential sponsors. A prime example of this is the reduction in the number of top level sponsors for the FIFA 2010 World Cup from 15 to 6 with the intention to make each sponsorship more valuable (Fullerton, 2007). This 'sponsorship clutter' presents a major challenge for companies seeking sponsorship opportunities.

Increasingly, sponsors seek to ensure that consumers are aware of their support of sponsored properties (Chien, Cornwell, and Pappu, 2011). By increasing consumer awareness, sponsors try to influence the development and depth of brand association, while increasing the chance that consumers will select the sponsoring brand (Crompton, 2004). Currently, 93\% of companies are involved with sport sponsorship with a primary objective to increase brand awareness (Yong et al., 2008); therefore, it is ever more important to determine how awareness impacts consumer response to sponsorship.

It has been suggested that sponsorship is particularly suitable for low involvement products (Lee, 2005; McDaniel, 1999), given that consumers choose between brands with common characteristics. Furthermore, packaging has also been identified as an extremely powerful and unique marketing tool and is critical stimulus to the creation and communication of brand identity; specifically for communicating brand meaning and strengthening the consumer-brand relationship (Underwood, 2003). As such, sponsorship packaging may provide a stronger point of differentiation for grocery products. These types of purchases belong in the category of low involvement purchases and are characterized by little cognitive investment by consumers, emotional decision-making, and low brand loyalty (Summers, Gardiner, Lamb, Hair, and McDaniel, 2005).

Given that both sponsorship and packaging play significant roles in developing brand image and awareness, it seems logical that they would also complement each other in a marketing strategy such as sponsorship packaging. Sponsorship packaging is widely used in the Australian grocery industry where the sponsored property's image and logo are depicted on the sponsoring brand's packaging (Woodside and 
Summers, 2011). Examples include Weetbix and the sponsorship of Kids Triathlon; Milo and the sponsorship of the Australian Institute of Sports; and Powerade and the sponsorship of the Wallabies.

While understanding that sponsorship is growing, little research has attempted to address the integrative effects of sponsorship in combination with packaging. Despite the suggestion that sponsorship is particularly suitable for low-involvement products, most sponsorship research has examined high-involvement product categories. The contribution of the current research is the development of a model of consumer response to sponsorship packaging; particularly in a low-involvement setting. The model includes factors that impact consumer response and moderate the role of awareness of the sponsorship. The proposed model was tested using real current market examples to answer the research question: "What role does awareness of the sponsorship play in consumer response to sponsorship packaging?'

\section{LITERATURE REVIEW}

Sponsorship involves two principal activities: (1) an exchange between sponsor and property, where the property receives compensation and the sponsor obtains the right to 'associate' itself with the property; and (2) leverage by the sponsor of this 'association' by developing marketing activities to communicate the sponsorship (Cornwell and Maignan, 1998). The 'association' component and, especially the emotional association, are particularly important to sponsorship, as the sponsored property may be linked in memory with the sponsoring brand (Keller, 1993). A strong sense of attachment with the sponsor may then be formed when consumers are emotionally involved with a sponsored property (Sirgy, Lee, Johar, and Tidwell, 2007; Gwinner and Eaton, 1999). Further, these associations may then be reflected in top-of-mind awareness of the brand, create greater preference for the brand, and lead the consumer to purchase the brand (Tripodi, 2001). Sponsorship messages, particularly when displayed on grocery packaging, are thought to provide important association cues for consumers to differentiate products when making purchase decisions.

A useful approach to understanding how consumers process marketing messages is provided by the elaboration likelihood model of persuasion (Petty and Cacioppo, 1986) (ELM). The ELM demonstrates that consumers process marketing communications, such as advertising and sponsorship, on a continuum that ranges from "low" cognition, motivation, and consumer involvement (peripheral route to persuasion) to extensive elaboration, motivation, and high involvement (central route 
to persuasion). In practical terms, the route to persuasion for consumers depends on the company's market position and the degree of positive consumer attitudes toward the brand or product. For market leaders, or where there is high favorable consumer attitudes, marketers prefer that consumers are motivated to take the peripheral route to persuasion and use their emotional attachment to the brand or product to make a purchase decision. When the product or brand is trying to gain the consumer's attention, change beliefs, or overtake a market leader, then marketers attempt to stimulate consumers to "think" about or elaborate on the messages that are incorporated into their marketing communications and activate the central route to persuasion. When this process is combined with the use of sponsorship, as a marketing tool, consumers become motivated and better able to elaborate when the message content (i.e., sponsorship) is relevant and when they have the knowledge and ability to think about the message.

The majority of sponsorship authors follow the hierarchical model of effects proposed by Lavidge and Steiner (1961), which considers three distinct stages of psychological response to a marketing communication or purchase situation: cognition; affection; and conation. As such, improving brand awareness and image via sponsorship are communication efforts that then lead to influencing purchase decisions (Meenaghan, 1983). However, it has been suggested that the cognitive function of sponsorship should be peripheral to its key role of reinforcing consumers to acquire a repeat purchasing habit of the sponsoring brand (Tripodi, 2001). Specifically, this is where the awareness, trial, and reinforcement (ATR) advertising model, by Ehrenberg (1974), suggests that sponsorship may work by reinforcing existing behaviors, rather than by persuading consumers to adopt new behaviors (Hoek and Gendall, 2003). This is of particular importance given that, in many sponsorship situations, marketing communications are secondary to the sponsored events or properties that audiences are involved. That is, the sidelines, arenas, and backgrounds of many events and cultural exhibits that will be accompanied by dozens of posters, signs, and verbal announcements of sponsoring brands (Olson and Thjømøe, 2003). However, as these sponsorship stimuli are minimal by nature, they cannot carry the wealth or quality of information as more complex communications (e.g., sponsorship packaging).

Thus, sponsorship packaging may prove to be a valuable tool where information, pictures, and logos can be incorporated to reinforce and extend the information provided in a typical sponsorship setting. This is particularly relevant given that the role and importance of packaging, today, has increased compared to other 
communication tools (Orth and Malkewitz, 2006; Underwood and Klein, 2002) and is considered one of the strongest associations a consumer can have with a brand (Keller, 1993). As such, this is a very important tool in building and reinforcing brand associations (Roper and Parker, 2006).

Table 2 provides a summary of a number of empirical articles that have been published relating to consumer response to sponsorship. Considering the low involvement context in this study, three other factors were identified as important when examining consumer response to sponsorship packaging: sponsored property identification, loyalty to the sponsoring brand, and perceived fit.

Sponsored property identification indicates the extent to which consumers identify themselves with a specific activity (be it leisure activity or a cause) through their engagement with the property (Grohs, Wagner, and Vsetecka, 2004) (e.g. the fanatic loyalty of an Australian Cricket Team fan). Empirical evidence suggests that sponsored property identification significantly affects image transfer from sponsored property to sponsoring brand (Cornwell and Coote, 2005; Daneshvary and Schwer, 2002; Meenaghan, 2001; Harris, 2000). In particular, consumers have been shown to have a higher intention to purchase the sponsor's product if they: identify with the sponsored property; if that property or cause is personally relevant; and if they perceive the source as credible. This suggests that sponsored property identification will positively impact the consumer's attitude and purchase intention toward the sponsored product.

Loyalty to the sponsoring brand: In today's competitive grocery industry, brand managers have attempted to tackle consumers' increasing price sensitivity by creating stronger brands. In these markets, the majority of consumer purchase decisions are made at the point-of-purchase (Harris, 2000) and promotion techniques are considered particularly important since on-package promotions can influence the consumer's decision (Johar and Pham, 1999). However, the literature also suggests an inverse relationship between brand loyalty and responsiveness to competitive promotion; that is, as brand loyalty increases vulnerability, competitive action is reduced (Aaker, 1999). This suggests that, in the case of sponsorship packaging, for consumers who are already loyal to a brand, sponsorship packaging may have little effect on purchase behavior. Alternatively, when a consumer is not loyal, sponsorship packaging may provide a point of differentiation and prompt consumers to consider the sponsored product.

Perceived fit: Research has suggested (Gwinner and Eaton, 1999) that the transfer of image (in this case - attitudes) from the sponsored property to the 
sponsoring brand is higher when the event and sponsor are congruent in either functionality or image. Studies that have examined perceptions of the sponsor-property relationship consistently suggest that the impact of a sponsorship is dependent on the fit between the property and sponsor (Speed and Thompson, 2000; Gwinner and Eaton, 1999; Meenaghan, 2001). In particular, a positively perceived sponsor-property fit has been shown to enhance consumer attitudes toward sponsorship (Cornwell, Humphreys, Maguire, Weeks, and Tellegen, 2003; McDaniel, 1999). In addition, congruency theory also suggests that the sponsor-property fit influences storage in memory and recall of information about the sponsorship arrangement (McDaniel, 1999).

Based on the literature, the components of a model of factors that impact consumer responses to sponsorship packaging were developed along with a series of hypotheses (see Table 1) to answer the research question: 'What role does awareness of the sponsorship play in consumer response to sponsorship packaging?'

Table 1 Research Hypotheses

There will be a positive relationship between sponsored property identification and consumer response to sponsorship packaging. That is, as the degree of sponsored

H1 property identification increases, there will be a positive impact on consumer response to sponsorship packaging.

There is a positive relationship between perceived fit and consumer response to

$\mathrm{H} 2$ sponsorship packaging. That is, as the degree of perceived fit increases, there will be a positive impact on consumer response to sponsorship packaging.

There is a negative relationship between sponsoring brand loyalty and consumer

H3 response to sponsorship packaging. That is, in cases of low sponsoring brand loyalty, there will be a positive impact on consumer response to sponsorship packaging.

Consumer response to sponsorship packaging is moderated by the awareness of the

H4 sponsorship. That is, in cases where the respondent is aware of the sponsorship; there will be a positive impact on consumer response to sponsorship packaging. 
Table 2 Sponsored Research Findings

\begin{tabular}{|c|c|c|}
\hline Ref. & Focus of Study & Findings \\
\hline Dardis, 2009 & $\begin{array}{l}\text { Congruence and repeated } \\
\text { exposure of message }\end{array}$ & $\begin{array}{l}\text { For a sponsor initially deemed incongruent, perceived } \\
\text { congruence mediated the positive effects of repeated } \\
\text { exposure on other brand evaluations. }\end{array}$ \\
\hline $\begin{array}{l}\text { Cornwell and } \\
\text { Coote, } 2005\end{array}$ & $\begin{array}{l}\text { Social identity theory used } \\
\text { to examine willingness to } \\
\text { purchase the sponsored } \\
\text { products }\end{array}$ & $\begin{array}{l}\text { Found a positive relation between consumers' } \\
\text { identification with the non-profit organization and } \\
\text { their intention to purchase its sponsor's products. }\end{array}$ \\
\hline $\begin{array}{l}\text { Grohs and } \\
\text { Reisinger, } \\
\quad 2005\end{array}$ & $\begin{array}{l}\text { Investigated strength of } \\
\text { image transfer in } \\
\text { sponsorship including } \\
\text { event-sponsor fit, } \\
\text { sponsorship exposure and } \\
\text { sponsor prominence. }\end{array}$ & $\begin{array}{l}\text { High Perceived Fit between event and sponsor and a } \\
\text { high sponsor prominence lead to an increased image } \\
\text { transfer. Longer sponsorship exposure resulted in a } \\
\text { smaller image transfer. If sponsorship exposure } \\
\text { interacted with event-sponsor fit, then the interaction } \\
\text { effect on the magnitude of image transfer was } \\
\text { positive. }\end{array}$ \\
\hline $\begin{array}{c}\text { Hamlin and } \\
\text { Wilson, } 2004\end{array}$ & $\begin{array}{l}\text { Fit between causes, } \\
\text { companies, products, and } \\
\text { brands in CRM. }\end{array}$ & $\begin{array}{l}\text { Degree of 'fit' between sponsor and property had a } \\
\text { significant effect on consumers' evaluations of } \\
\text { products that carry a cause 'brand identity' as part of } \\
\text { a CRM campaign. Cause cues in low-involvement } \\
\text { purchase situations created their impact by disrupting } \\
\text { existing decision heuristics }\end{array}$ \\
\hline $\begin{array}{l}\text { Rifon, Choi, } \\
\text { Trimble, and } \\
\text { Li, } 2001\end{array}$ & $\begin{array}{l}\text { Consumer attributes of } \\
\text { sponsor motives and } \\
\text { influence on fit }\end{array}$ & $\begin{array}{l}\text { Sponsor-cause congruence was associated with } \\
\text { attributes of altruistic motives, greater sponsor } \\
\text { credibility, and positive attitudes about sponsors. } \\
\text { Congruence effects were mediated by sponsor } \\
\text { credibility. }\end{array}$ \\
\hline $\begin{array}{c}\text { Cornwell et } \\
\text { al., } 2003\end{array}$ & $\begin{array}{l}\text { Manipulate congruence } \\
\text { and level of sponsor and } \\
\text { property }\end{array}$ & $\begin{array}{l}\text { Recall was better for congruent sponsors than for } \\
\text { incongruent sponsors. Recall for incongruent } \\
\text { sponsors improved with articulation }\end{array}$ \\
\hline $\begin{array}{l}\text { Olson and } \\
\text { Thjømøe, } \\
2003\end{array}$ & $\begin{array}{l}\text { Examined sponsorship } \\
\text { with low-involvement } \\
\text { products and in cases with } \\
\text { limited processing }\end{array}$ & $\begin{array}{l}\text { Findings indicated that individuals who had } \\
\text { processed the additional brand information had a } \\
\text { greater attitude change than those who were exposed } \\
\text { to the information but did not process it. }\end{array}$ \\
\hline $\begin{array}{l}\text { Becker-Olsen } \\
\text { and } \\
\text { Simmons, } \\
2002\end{array}$ & $\begin{array}{l}\text { Compare effects of native } \\
\text { fit }\end{array}$ & $\begin{array}{l}\text { Effects of fit on firm equity were completely } \\
\text { mediated by attitude toward the sponsorship and } \\
\text { perceived clarity of the sponsor's positioning. Low fit } \\
\text { decreased equity relative to no sponsorship, while } \\
\text { high fit increased equity. Effects of created fit were } \\
\text { parallel those observed for native fit and remained } \\
\text { significant up to one year later. }\end{array}$ \\
\hline
\end{tabular}

(Source: developed for this study) 
Table 2 Sponsored Research Findings (Continued)

\begin{tabular}{|c|c|c|}
\hline Ref. & Focus of Study & Findings \\
\hline $\begin{array}{l}\text { Madrigal, } \\
2000\end{array}$ & $\begin{array}{l}\text { Examined how consumers' } \\
\text { identification level } \\
\text { influences their attitudes } \\
\text { toward sponsor \& P.I. }\end{array}$ & $\begin{array}{l}\text { Team identification was found to moderate the effect } \\
\text { of attitude on intention to purchase. }\end{array}$ \\
\hline Harris, 2000 & $\begin{array}{l}\text { Examined how social } \\
\text { alliances between sports } \\
\text { fans and preferred sports } \\
\text { teams influence P.I. }\end{array}$ & $\begin{array}{l}\text { Purchase intentions toward sponsored products were } \\
\text { greater among those who identified with the team } \\
\text { being sponsored and when such intentions were } \\
\text { perceived to be the group norm. }\end{array}$ \\
\hline $\begin{array}{l}\text { Speed and } \\
\text { Thompson, } \\
2000\end{array}$ & $\begin{array}{l}\text { Used a classical } \\
\text { conditioning framework to } \\
\text { examine consumers' } \\
\text { attitudes about sponsors, } \\
\text { events, and perceptions of } \\
\text { sponsor-event fit. }\end{array}$ & $\begin{array}{l}\text { Response to sponsorship was stronger when } \\
\text { consumers perceived a sponsor-property fit. Attitude } \\
\text { toward the sponsor was positively associated with } \\
\text { response to sponsorship. Positive relationship } \\
\text { between fit and personal liking of property. } \\
\text { Consumer response was influenced by attitudes } \\
\text { toward the sponsor, perceived sponsor-event fit, and } \\
\text { the perceived sincerity and ubiquity of the sponsor. } \\
\text { Fit moderated the impact of attitude toward the ad }\end{array}$ \\
\hline $\begin{array}{c}\text { Johar and } \\
\text { Pham, } 1999\end{array}$ & $\begin{array}{l}\text { Three experiments } \\
\text { investigated brand-event } \\
\text { fit \& market prominence. }\end{array}$ & $\begin{array}{l}\text { Consumers (mis)identified sponsors as being those } \\
\text { companies that were congruent with the event being } \\
\text { sponsored and were more prominent in the } \\
\text { marketplace }\end{array}$ \\
\hline $\begin{array}{l}\text { Gwinner and } \\
\text { Eaton, } 1999\end{array}$ & $\begin{array}{l}\text { Assessed the degree to } \\
\text { which a sporting event's } \\
\text { image was transferred to a } \\
\text { brand via a sponsorship } \\
\text { activity. }\end{array}$ & $\begin{array}{l}\text { When event and brand were matched on either an } \\
\text { image or functional basis, the transfer process was } \\
\text { enhanced, which indicated that, if the match between } \\
\text { event and product could be made stronger, then the } \\
\text { resulting image transfer would be more pronounced. }\end{array}$ \\
\hline $\begin{array}{l}\text { Gwinner, } \\
1997\end{array}$ & $\begin{array}{l}\text { Presented a model to } \\
\text { identify factors that } \\
\text { influence the creation of an } \\
\text { event's image. }\end{array}$ & $\begin{array}{l}\text { Proposed that an event's image associations are } \\
\text { transferred to the sponsor via sponsorship activities, } \\
\text { moderated by degree of fit, level of sponsorship, } \\
\text { event frequency, product involvement. }\end{array}$ \\
\hline
\end{tabular}

(Source: developed for this study)

\section{RESEARCH METHODOLOGY AND FINDINGS}

From the previous discussion, a conceptual model was developed that proposes the relationship between awareness of sponsorship and its impact on consumer response to sponsorship packaging (see Figure 1). The model consists of three independent variables: Sponsored Property Identification; Sponsoring Brand Loyalty; and Perceived Fit; and one dependent variable: Consumer Response to Sponsorship 
Packaging (as measured by an aggregation of attitudes toward the sponsoring brand and purchase intention toward the sponsor's product). The larger the measure of consumer response to sponsorship packaging, the stronger the attitudes toward the brand and the stronger purchase intentions. Finally, awareness of sponsorship was proposed to moderate these relationships.

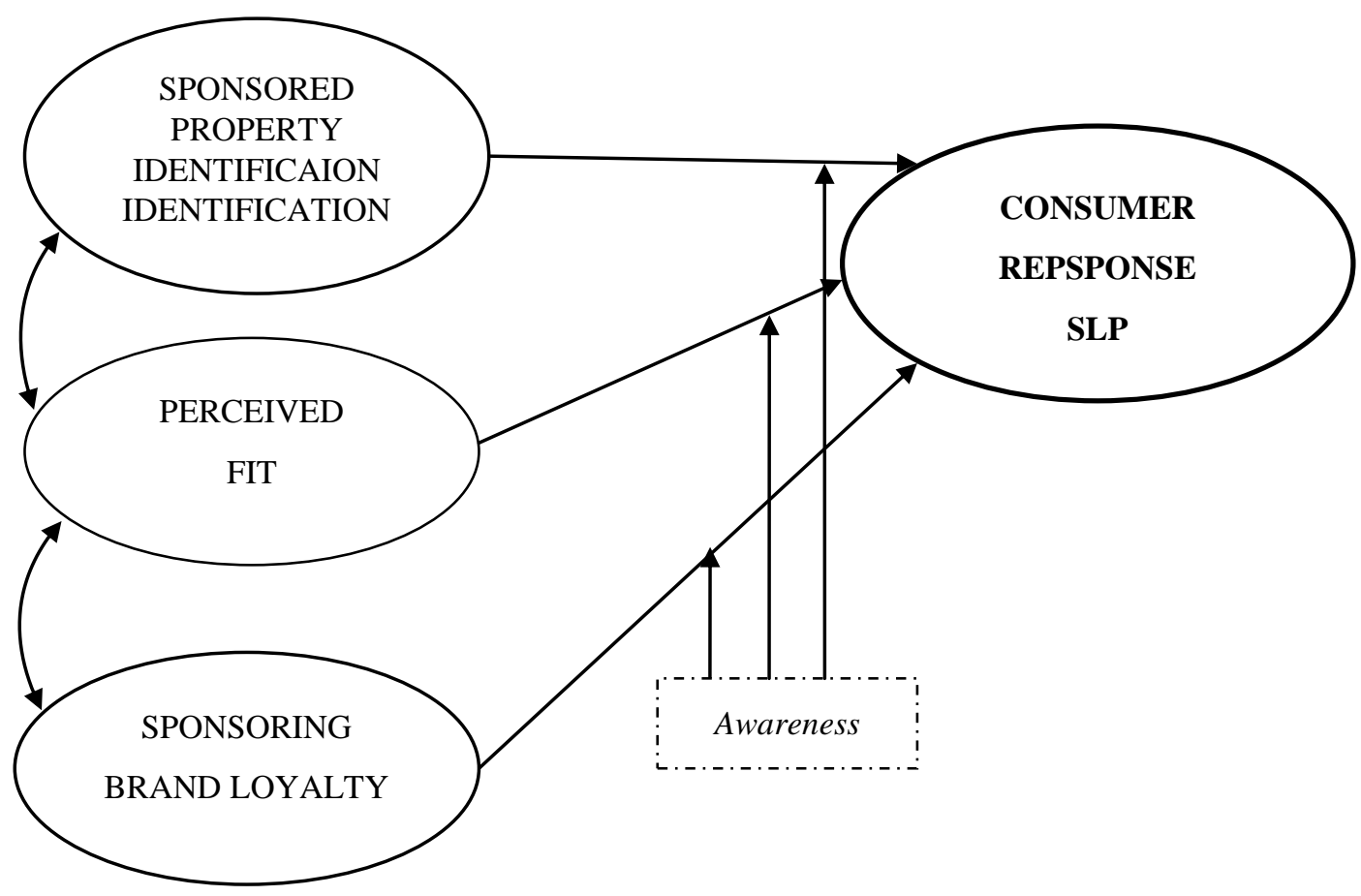

Figure 1 Conceptual model of Consumer Response to Sponsorship Packaging

A self-administered survey was used to test the interrelationships of the factors in the proposed model. Sponsorship packaging is commonly used in such categories as sports drink, snack bars, personal care products, and breakfast cereal products. Given that the majority of Australian children regularly eating breakfast cereals (Woods and Walker, 2007) and the substantial contribution that the breakfast cereal market makes to the Australian grocery industry ( $\$ 894$ billion dollars, annually), it was decided that the breakfast cereal category would provide suitable examples to be used in the questionnaires. A judgment was made that school networks within a large regional city in Queensland, would provide access to a considerable number of families (and thus household shoppers). Questionnaires were distributed to each family, who were asked to complete and returned them within a one week time frame. With 440 families being represented, the final number of responses was 256 (58\% response rate). The 
data for this paper considered 206 respondents in the sponsorship packaging group; five cases had missing data in excess of $15 \%$ and were removed from the data set. As a result, 201 usable surveys were collected; a demographic profile of the respondents is provided in Table 3 .

The data was analyzed using SPSS (descriptive analysis, tests of differences, and multiple regression) and structural equation modeling and multi-group analyses were conducted using AMOS software. Scales were adapted from previous sponsorship studies (see Table 4).

During data cleaning, it was noted that the question relating to trial intention appeared to be problematic. Despite directions to skip this question if the respondents had previously purchased the sponsored product, some respondents completed this question (10\%). The question was therefore eliminated from the analysis.

Table 3 Demographic Profile of Respondents

\begin{tabular}{|c|c|c|c|}
\hline Demographic Profile & Frequency $(\%)$ & Demographic Profile & Frequency $(\%)$ \\
\hline $\begin{array}{l}\text { Gender } \\
\text { - } \quad \text { Female } \\
\text { - } \quad \text { male }\end{array}$ & $\begin{array}{r}N=206 \\
175(85) \\
31(15)\end{array}$ & $\begin{array}{l}\text { Household Status } \\
\text { - } \quad \text { Single } \\
\text { - } \quad \text { Couple }\end{array}$ & $\begin{array}{r}N=201 \\
45(23) \\
156(77)\end{array}$ \\
\hline 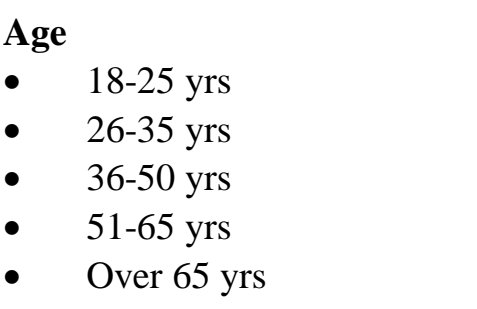 & $\begin{array}{r}\mathrm{N}=197 \\
26(13) \\
47(24) \\
96(49) \\
24(12) \\
4(2)\end{array}$ & $\begin{array}{l}\text { Children living at home } \\
\text { - } \quad \text { Yes } \\
\text { - } \quad \text { No }\end{array}$ & $\begin{array}{r}\mathrm{n}=201 \\
151(75) \\
50(25)\end{array}$ \\
\hline $\begin{array}{ll}\text { Occupation } \\
\text { - } & \text { Managerial/Professional } \\
\text { - } & \text { Semi-professional } \\
\text { - } & \text { Tradesperson/ sales } \\
\text { - } & \text { Administration } \\
\text { - } & \text { Student } \\
\text { - } & \text { Home Duties } \\
\text { - } & \text { Retired/ Unemployed }\end{array}$ & $\begin{array}{r}\mathrm{N}=197 \\
23(12) \\
58(29) \\
19(9) \\
31(16) \\
41(21) \\
21(11) \\
4(2)\end{array}$ & $\begin{array}{ll}\text { Household Income } \\
\text { - } \quad \text { Under } \$ 25000 \\
\text { - } \quad \$ 25000 \& \text { under } \$ 50000 \\
\text { - } \quad \$ 50000 \& \text { under } \$ 75000 \\
\text { - } \quad \$ 75000 \& \text { under } \$ 100000 \\
\text { - } \quad \$ 100000 \text { or over }\end{array}$ & $\begin{array}{l}\mathrm{N}=144 \\
20(14) \\
26(18) \\
42(29) \\
29(20) \\
27(19)\end{array}$ \\
\hline
\end{tabular}


Table 4 Operationalization of the Questionnaire

\begin{tabular}{|c|c|c|c|}
\hline Variable & Question & Scale & Author \\
\hline $\begin{array}{l}\text { Frequency } \\
\text { of purchase }\end{array}$ & $\begin{array}{l}\text { How often do you purchase (sponsoring } \\
\text { brand)? } \\
1=\text { weekly } 2=\text { fortnightly } 3=\text { monthly } \\
4=\text { occasionally } 5=\text { never }\end{array}$ & 5-point scale & $\begin{array}{l}\text { Gwinner and } \\
\text { Swanson, } \\
2003\end{array}$ \\
\hline $\begin{array}{l}\text { Sponsored } \\
\text { Property } \\
\text { Identification }\end{array}$ & $\begin{array}{l}\text { I am a strong supporter of (specified } \\
\text { property). } \\
\text { I am interested in (specified property). } \\
\text { If a company sponsored (specified property), } \\
\text { it would positively influence how I felt about } \\
\text { that company. } \\
\text { It is good that companies sponsor (specified } \\
\text { property). } \\
\text { I am more likely to purchase products of } \\
\text { companies that sponsor (specified property). }\end{array}$ & $\begin{array}{l}5 \text {-point Likert scale } \\
1=\text { strongly agree } \\
5=\text { strongly } \\
\text { disagree }\end{array}$ & $\begin{array}{l}\text { Speed and } \\
\text { Thompson, } \\
2000\end{array}$ \\
\hline $\begin{array}{l}\text { Sponsoring } \\
\text { Brand } \\
\text { Loyalty }\end{array}$ & $\begin{array}{l}\text { I like this brand. } \\
\text { This brand is reliable. } \\
\text { I would recommend this brand to others. } \\
\text { I have a favorable opinion of this brand. } \\
\text { I am loyal to this brand. }\end{array}$ & $\begin{array}{l}\text { 5-point Likert scale } \\
\text { Agree/ disagree }\end{array}$ & $\begin{array}{l}\text { Sen, } \\
\text { Gurhan-Canli, } \\
\text { and Morwitz, } \\
\text { 2001; } \\
\text { Dahl, } \\
\text { Manchanda, } \\
\text { and Argo, } \\
\text { 2001; } \\
\text { Ahluwalia, } \\
\text { Burnkrant, } \\
\text { and Unnava, } \\
2000\end{array}$ \\
\hline $\begin{array}{l}\text { Attitude } \\
\text { toward the } \\
\text { Sponsor }\end{array}$ & $\begin{array}{l}\text { This sponsorship makes me more favorable } \\
\text { toward the sponsor. } \\
\text { This sponsorship would improve my } \\
\text { perception of the sponsor. } \\
\text { This sponsorship would make me like the } \\
\text { sponsor more. }\end{array}$ & $\begin{array}{l}\text { 5-point Likert scale } \\
\text { Agree/ disagree }\end{array}$ & $\begin{array}{l}\text { Speed and } \\
\text { Thompson, } \\
2000\end{array}$ \\
\hline $\begin{array}{l}\text { Trial } \\
\text { Intention }\end{array}$ & $\begin{array}{l}\text { Would you try this product because of the } \\
\text { sponsorship? }\end{array}$ & Yes / No & $\begin{array}{l}\text { Gwinner and } \\
\text { Swanson, } \\
2003\end{array}$ \\
\hline $\begin{array}{l}\text { Purchase } \\
\text { intention }\end{array}$ & $\begin{array}{l}\text { I would purchase this sponsored product. } \\
\text { I would buy more of this product with a } \\
\text { sponsorship than non-sponsored. }\end{array}$ & $\begin{array}{l}\text { 5-point Likert scale } \\
\text { Agree/ disagree }\end{array}$ & $\begin{array}{l}\text { Cornwell and } \\
\text { Coote, } 2005\end{array}$ \\
\hline
\end{tabular}


Table 4 Operationalization of the Questionnaire (Continued)

\begin{tabular}{llll}
\hline \multicolumn{1}{c}{ Variable } & \multicolumn{1}{c}{ Question } & \multicolumn{1}{c}{ Scale } & \multicolumn{1}{c}{ Author } \\
\hline & & & $\begin{array}{l}\text { Speed and } \\
\text { Thompson, } \\
\text { Its logical for (brand) to sponsor (specified } \\
\text { Perceived } \\
\text { Fit }\end{array}$ \\
& $\begin{array}{l}\text { property) } \\
\text { (Brand) \& (specified property) have a similar } \\
\text { image. }\end{array}$ & $\begin{array}{l}\text { 5-point Likert scale } \\
\text { Agree/ disagree }\end{array}$ & $\begin{array}{l}\text { Grohs, } \\
\text { Wagner, and } \\
\text { Vsetecka, } \\
2004\end{array}$ \\
\hline Awareness & $\begin{array}{l}\text { Were you aware of this sponsorship before } \\
\text { today? }\end{array}$ & Yes/No & This study \\
\hline $\begin{array}{l}\text { Respondent } \\
\text { Profile }\end{array}$ & $\begin{array}{l}\text { Gender, age, household status (children living } \\
\text { at home), country of birth and occupation. }\end{array}$ & Categorical values: & This study \\
\hline
\end{tabular}

The conceptual model of Factors Impacting Consumer Response to Sponsorship was assessed via confirmatory factor analysis (CFA) using a maximum likelihood estimation method. The internal consistency and reliability of the scales was examined using Cronbach alpha, where all scales exhibited alphas greater than 0.70 , as recommended by Nunnally (1978). The alpha scores for each scale are reported in Table 5.

Table 5 Construct Descriptive Statistics

\begin{tabular}{lccc}
\hline \multicolumn{1}{c}{$\mathrm{N}=201$} & $\alpha$ & Mean & Std. Deviation \\
\hline *Sponsored Property Identification & 0.884 & 2.94 & 0.787 \\
\hline *Sponsoring Brand Loyalty & 0.949 & 3.27 & 0.906 \\
\hline *Consumer Response to SP & 0.892 & 2.58 & 0.850 \\
\hline *Perceived Fit & 0.841 & 2.81 & 0.966 \\
\hline
\end{tabular}

In the interests of increasing the stability of the data and reducing the degree of non-normality of the data, item parceling was used in the final measurement model. Parcels were constructed by summing and averaging the item responses for each construct. Regression coefficients and measurement error variances were calculated using Munck's (1979) formula, which was based on the standard deviations and Cronbach alpha for each scale. These parceled items were used as indicator variables of the sponsored property identification, sponsoring brand loyalty, perceived fit, and consumer response to sponsorship packaging constructs in the SEM. Item parceling increases the ratio of parameters that are estimated to sample size and are appropriate 
when sample sizes are small (Bandalos, 2002; Little, Cunningham, Shahar, and Widaman, 2002).

\section{Hypotheses 1-3 Property Identification, Perceived Fit, \& Sponsoring Brand Loyalty}

The results of the SEM showed that the relationship between Sponsored Property Identification and Consumer Response to Sponsorship Packaging was significant (beta $=0.357 ; t=5.087 ; p<0.01)$. The relationship between Perceived Fit and Consumer Response to Sponsorship Packaging was significant (beta $=0.516 ; t=3.908 ; p=$ $<0.01)$. However, the relationship between Sponsoring Brand Loyalty and Consumer Response to Sponsorship Packaging was not significant (beta $=0.131 ; t=1.605 ; p$ $=.109)$. These results indicate that consumer's identification with the sponsored property and the perceived fit between the sponsored property and sponsoring brand are important factors that influence Consumer Response to Sponsorship Packaging. However, the results also indicated that consumer's loyalty to the sponsoring brand had little impact on their response to the sponsorship packaging. The fit statistics were also indicative of a good fit $\left(\chi^{2}(\mathrm{df} 1)=0.053\right.$, $\mathrm{bp}=.466$; TLI $=1.02$, RMSEA 0.00, SRMR .02). This suggests that the data collected was an accurate reflection of the specified model that was developed from the literature and exploratory research.

\section{Hypothesis 4 - Awareness of Sponsorship}

To determine the impact of awareness on consumer response to sponsorship packaging, the sample was divided into two groups: respondents who indicated that they were aware of the selected sponsorship and those who were not. The aware group (Group 1) consisted of 66 respondents (33\% of the sample) and the unaware group (Group 2) consisted of 135 respondents (67\% of the sample). A multi-group analysis was then conducted. The properties of the data analysis were specified to examine five different models, which included unconstrained, measurement weights, structural weights, structural covariance, and structural residuals. The results of the multi-group analysis for Awareness of the Sponsorship indicated that the models fit the data well for the unconstrained (Bollen Stein $p^{*}=0.956$ ), structural weights (Bollen Stein $p^{*}=$ 0.960 ), structural covariance (Bollen Stein $p^{*}=0.825$ ), and measurement residuals models (Bollen Stein $p^{*}=0.857$ ), which indicates support for configural and metric invariance.

The measures of fit indicate that the model fits for both the aware and unaware groups concerning the different constructs, construct measures, and predicted 
relationships were not required for the different groups. Measures of fit for the models are provided in Table 6. The structural model of Factors Impacting Consumer Response to Sponsorship Packaging explained $43 \%$ of the variance in the model.

Table 6 Measures of Fit - Awareness of the Sponsorship

\begin{tabular}{ccccccc}
\hline & Model & Unconstrained & $\begin{array}{c}\text { Measurement } \\
\text { Weights }\end{array}$ & $\begin{array}{c}\text { Structural } \\
\text { Weights }\end{array}$ & $\begin{array}{c}\text { Structural } \\
\text { Covariance }\end{array}$ & $\begin{array}{c}\text { Structural } \\
\text { Residuals }\end{array}$ \\
\hline BollenStine $p$ & 0.466 & 0.956 & 0.956 & 0.960 & 0.825 & 0.857 \\
\hline CMIN/DF & $\begin{array}{c}\chi^{2}(\mathrm{df} \\
1)=0.05\end{array}$ & $\chi^{2}(\mathrm{df} 2)=0.82$ & $\chi^{2}(\mathrm{df} 2)=0.82$ & $\begin{array}{c}\chi^{2}(\mathrm{df} 5) \\
=1.11\end{array}$ & $\begin{array}{c}\chi^{2}(\mathrm{df} 10)= \\
6.75\end{array}$ & $\begin{array}{c}\chi^{2}(\mathrm{df} 11)= \\
6.82\end{array}$ \\
\hline GFI & 0.999 & 1.00 & 1.00 & 0.997 & 0.982 & $0 . .982$ \\
\hline AGFI & 0.987 & 0.998 & 0.998 & 0.989 & 0.966 & 0.967 \\
\hline TLI & 1.02 & 1.096 & 1.096 & 0.107 & 1.033 & 1.038 \\
\hline RMSEA & 0.00 & 0.000 & 0.000 & 0.000 & 0.000 & 0.000 \\
\hline SRMR & 0.02 & 0.011 & 0.011 & 0.022 & 0.025 & 0.025 \\
\hline
\end{tabular}

The $p$ values and unstandardized regression weights were examined for both groups. The results suggest that there was no difference between the groups for the relationship between Sponsored Property Identification and Consumer Response to Sponsorship Packaging (Group 1: $\mathrm{b}=0.310, p=.019$; Group 2: $\mathrm{b}=0.405, p<0.01$ ); this relationship was significant for both groups. Similarly, the results suggest that there was no difference between the groups for the relationship between Sponsoring Brand Loyalty and Consumer Response (Group 1: $\mathrm{b}=0.177, p=.178$; Group 2: $\mathrm{b}=$ $0.082, p=0.447$ ); the relationship was not significant for both groups. However, the relationship between Perceived Fit and Consumer Response to Sponsorship Packaging was significant for Group $2(\mathrm{~b}=0.499, t=3.109 ; p=.002)$ but was not significant for Group $1(\mathrm{~b}=0.490, t=1.687, p=.092)$. Table 7 provides the regression coefficients. Figure 2 shows the model. 


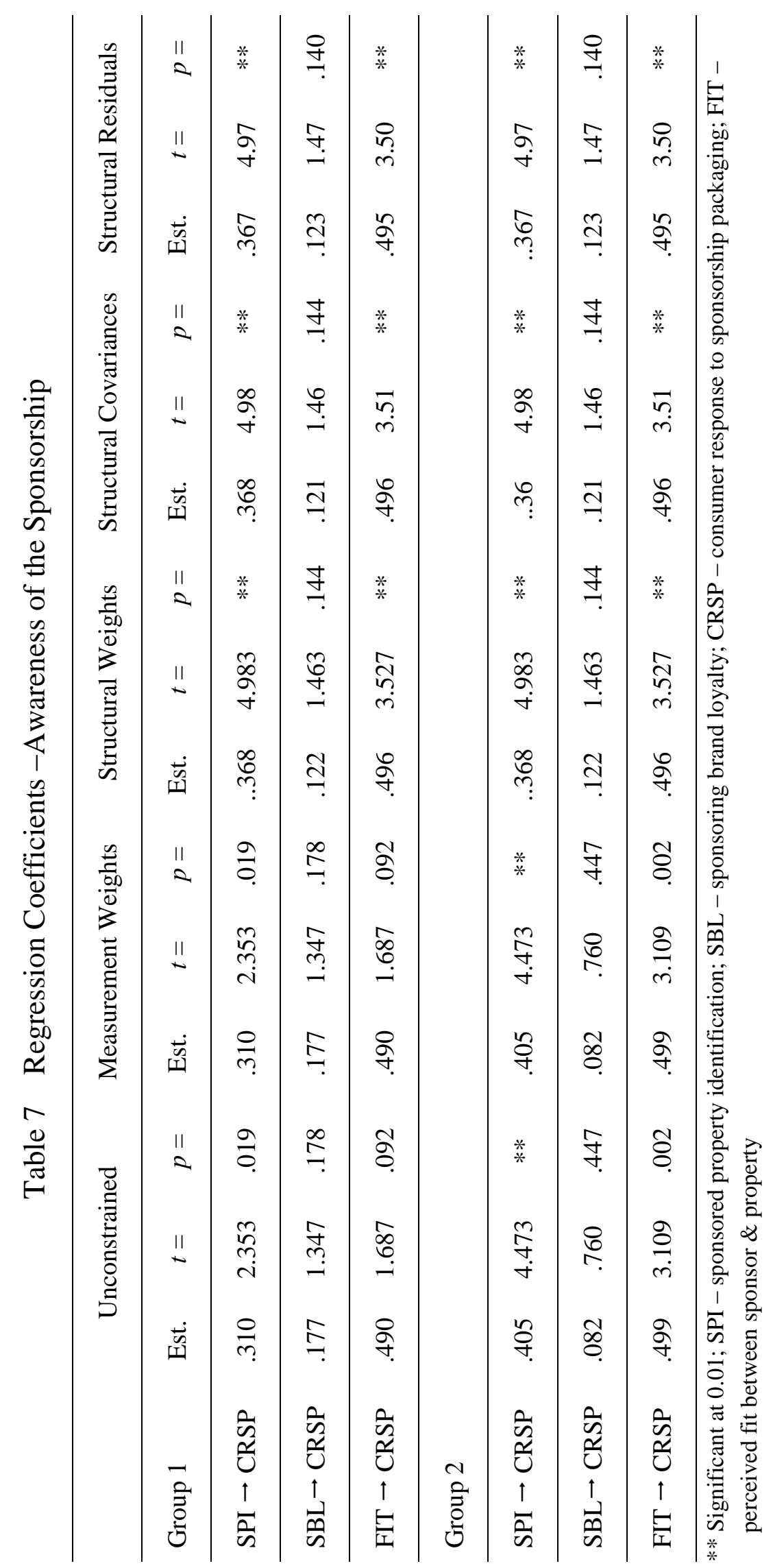


These results indicate that, for consumers who were not aware of the sponsorship, the perceived fit between the sponsoring brand and sponsored property had a much larger impact on Consumer Response to Sponsorship Packaging than it did for those consumers who were aware of the sponsorship. Thus, awareness played a moderating role in the relationship between perceived fit and consumer response to sponsorship packaging.

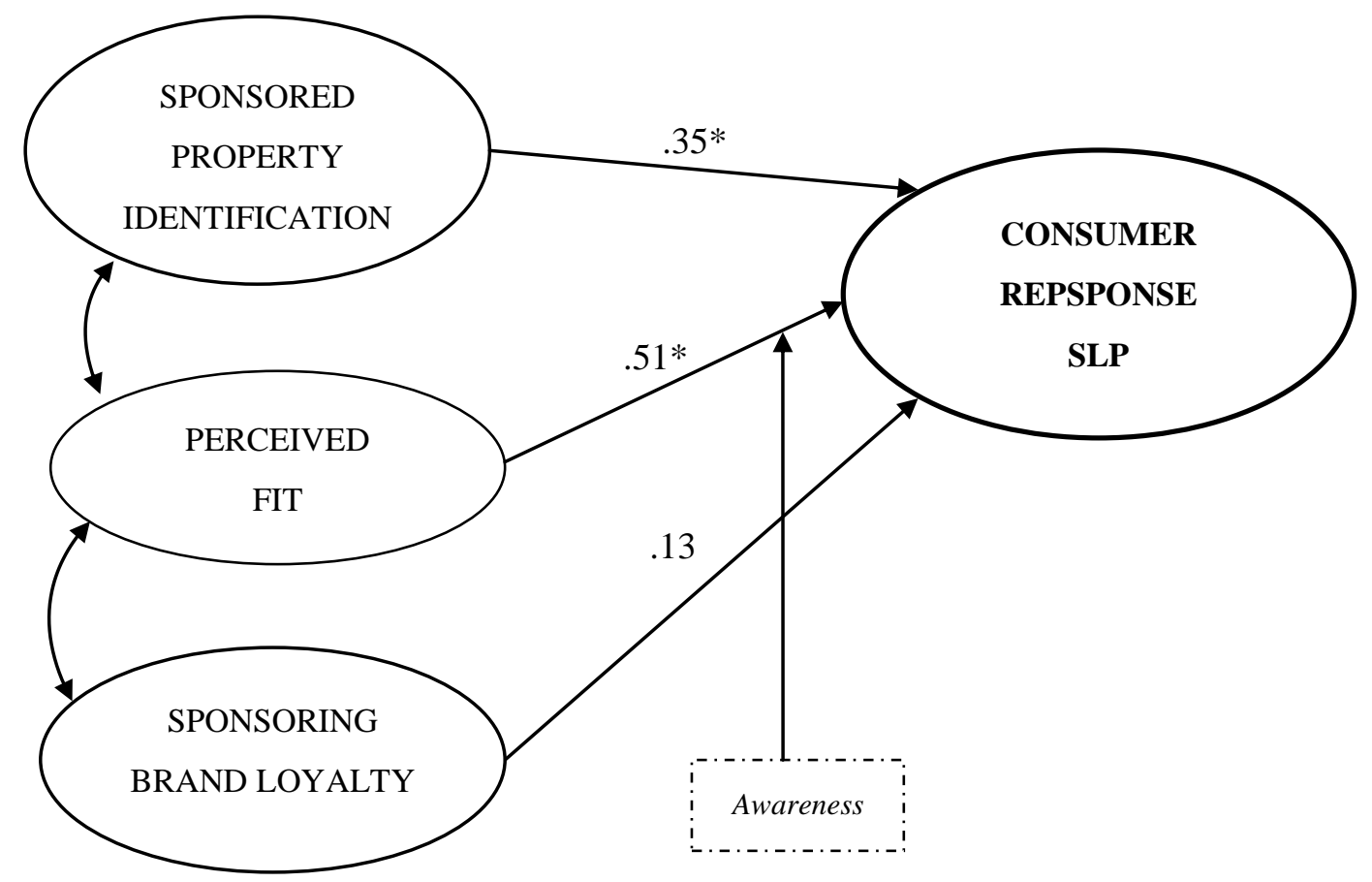

*significant at 0.01 level

Figure 2 Factors Impacting Consumer Response to Sponsorship Packaging

However, it should be noted that this sample size came close to violating a principal assumption in SEM. It has been proposed that an optimal ratio of the number of participants to the number of estimated parameters should be between 10:1 and 20:1, with a ratio of less than 5:1 indicating that the parameter estimates may be unstable (Kline, 1998). Group 1 in this study had a ratio of roughly 7:1. Therefore, these results must be interpreted with caution as the small group size may have influenced the parameter estimates and, therefore, the measures of fit may have had a higher chance of being serendipitous rather than the result of statistical significance. Future research should ensure sufficient responses are collected from people who are aware of the sponsorship prior to the study to allow a ratio between 10:1 and 20:1. 


\section{Trial Intention}

As an alternative indication for trial intention, the responses for frequency of purchase were also used to determine the number of respondents who were willing to try the product. Of those respondents who had not previously bought the sponsoring brand's product, $15 \%(N=15)$ indicated they would be likely to purchase the sponsored product following their exposure to the sponsorship packaging. This finding suggests that sponsorship packaging may have some capacity to induce trial; however, more research is needed to determine this.

\section{DISCUSSION AND IMPLICATIONS}

The findings reported above, as part of a larger study, indicate that leveraging sponsorship on grocery packaging influences consumer response to sponsorship. This research identified a positive relationship between sponsored property identification and consumer response to sponsorship packaging, which indicates that sponsorship packaging, particularly in a low-involvement product context, has the capacity to influence consumer response toward the sponsoring brand when sponsored property identification is high. This finding is consistent with previous studies that, when consumers are emotionally involved with a sponsored property and identify with it, this can lead to a strong sense of attachment with related sponsored brands (Sirgy et al., 2007; Gwinner and Swanson, 2003; Gwinner and Eaton, 1999; Harris, 2000; Meenaghan, 2001).

However, the finding that loyalty to the sponsoring brand has little impact on consumer response to sponsorship packaging is in contrast to the majority of previous sponsorship research, which has suggested that positive attitudes toward a sponsor are associated with favorable perceptions and intentions to purchase a sponsor's product (Gwinner, 1997; Pope and Voges, 1999; Speed and Thompson, 2000). The literature also suggests that attitudes and opinions are important precursors to behavioral intentions, in general; however, authors have found that, in low-involvement purchase decisions (e.g., grocery products), positive opinions about the brand have a weak or limited impact on purchase intentions of the sponsor's brand (Hoek, Gendall, and Theed, 1999; Lacey, Sneath, Finney, and Close, 2007). This suggests that, although sponsorship can reinforce beliefs already held by consumers, it is unlikely that they prompt new beliefs or behaviors in the context of low-involvement decision making.

In considering the role that awareness plays in consumer responses to sponsorship packaging, respondents from both the aware group and the unaware groups indicated positive improvements in attitude and purchase intentions toward the 
sponsors' products (i.e., consumer response to sponsorship packaging). However, prior awareness of the sponsorship arrangement, in this study, did not significantly impact consumer responses to sponsorship packaging. These findings are similar to (Alexandris, Douka, Bakaloumi, and Tsasousi, 2008) where respondents reported positive attitudes toward sponsorship, regardless of awareness.

The results further suggest that prior awareness of the sponsorship moderates the relationship between Perceived Fit and Consumer Response to Sponsorship Packaging. This means that, when a consumer is aware of the sponsorship relationship prior to exposure to sponsorship packaging, their perception of the match between the sponsoring brand and sponsored property has a lesser impact on their response than for those who were not aware of the sponsorship. This demonstrates the importance of emphasizing fit when a new sponsorship is introduced or when an effort is made to increase awareness. The findings from the current study indicate that, in a low-involvement context, awareness may not be an essential part of the consumer decision-making process. Rather, in this context, awareness may not even occur before a purchase. This is likely to be a result of the low involvement nature in such decisions where the sponsorship message would be considered a peripheral cue that is intended to aid in speeding up the purchase decision process.

Theoretically, the results of this study indicate that while some respondents progressed to the first stage of the hierarchy (i.e., awareness), there was not, in all cases, a corresponding impact on attitudes or purchase intentions. Importantly, researchers have suggested that it is critical to reinforce awareness of the relationship between the sponsoring brand and sponsored property (Fullerton, 2007), given that, if awareness is not achieved, it is difficult for the other stages of the hierarchy (e.g., attitudes and purchase behaviors) to be achieved. Moreover, while research has shown that sponsorship is capable of creating awareness (Johar and Pham, 1999; Rifon et al., 2001; Speed and Thompson, 2000), there is inconclusive evidence that awareness, or the subsequent development of positive attitudes toward the sponsor, would prompt trial. As such, more work is needed to explore the relationship between sponsorship packaging and consumers' trial intentions.

Furthermore, it was determined that the level of perceived fit impacted consumer response to the sponsorship packaging and that awareness of the sponsorship moderated this relationship. These findings are important because they support prior research by re-emphasizing the vital role that perceived fit plays in sponsor-related evaluations (Dardis, 2009). This will be an important finding for grocery managers who are considering the use of sponsorship packaging in their marketing activities. 
Further, it these marketing managers are able to increase the degree of perceived fit between their brands and those sports or causes that they sponsor, there is likely to be a resultant increase in consumer responses to the sponsorship. This reinforces the need for careful and strategic selection of sponsorship alliances and associations for retail organizations.

Given that the majority of companies who are involved with sponsorship, or sport sponsorship, in particular, have a primary objective to increase brand awareness (Yong et al., 2008), the findings from this study are particularly important. Specifically, this study clearly indicated that awareness alone does not guarantee consumer response. For sponsorship managers, this means that measuring awareness alone is not enough when evaluating the effectiveness of sponsorship. For property managers, this means that understanding the attitudes and level of awareness of consumers toward possible sponsor brands is crucial in selecting which sponsors to partner with. As such, these findings indicate that brand managers would benefit from selecting those properties for which consumers already have a strong affinity or identification.

\section{CONCLUSION}

Although sponsorship has become an increasingly important and popular means of promotion, previous research has not considered its contribution in a packaging context.

This study provided an understanding of the role of awareness in consumer response to sponsorship packaging in a low-involvement setting. This is relevant to two key elements of the sponsorship process: (1) the sponsorship selection decision and (2) the development of the sponsorship-leveraging strategy. In the sponsorship selection decision, managers must choose between alternative properties that serve as sponsorship vehicles. Therefore, brand managers should target properties that their target market values highly and can clearly realize a high measure of fit between the property and sponsoring brand. This will allow brand and property managers to assess new and existing sponsorship arrangements in order to maximize the benefit gained from such opportunities and avoid costly mistakes.

Secondly, in developing the sponsorship-leveraging strategy, the current findings provide support for incorporating sponsorship packaging, particularly in a grocery setting. Sponsorship packaging provides the opportunity to further engage the consumer in the sponsor's product by reinforcing the link between the favored property and the sponsor. While providing a way to communicate the sponsorship 
arrangement to consumers at a point closer to purchase than traditional sponsorship promotion (i.e., venue and media advertising), marketers should also consider the role of awareness and its impact on the relationship of perceived fit and consumer response to sponsorship packaging.

This study concentrated on one type of treatment of an experiment condition (i.e., exposure to sponsorship packaging from a real world example). A longitudinal study that considers the change of consumer response over time would be beneficial to provide further insight into the area. Furthermore, a study that examines the effectiveness of sponsorship packaging, compared to other tools (e.g., competitions, celebrity endorsement, licensing), and their capacity to create awareness and improve brand attitudes and purchase intentions, will determine the commercial value of sponsorship packaging for grocery managers. Future research could also examine different grocery categories and determine whether the findings from this study hold strong for other product categories.

\section{REFERENCES}

Aaker, D. (1991). Managing Brand Equity. New York, U. S.: The Free Press.

Ahluwalia, R., Burnkrant, R., \& Unnava, R. (2000). Consumer response to negative publicity, the moderating role of commitment. Journal of Marketing Research, 37(May), 203-214.

Alexandris, K., Douka, S., Bakaloumi, S., \& Tsasousi, E. (2008). The influence of spectators' attitudes on sponsorship awareness: a study in three different leisure events. Managing Leisure, 13(1), 1-12.

Bandalos, D. L. (2002). The effects of item parcelling on the goodness-of-fit and parameter estimate bias in structural equation modelling. Structural Equation Modeling, 9(1), 78-102.

Becker-Olsen, K. \& Simmons, C. J. (2002). When Do Social Sponsorships Enhance or Dilute Equity? Fit, Message Source, and the Persistence of Effects. Advances in Consumer Research, 29(1), 287-289.

Chien, P. N., Cornwell, T. B., and Pappu, R. (2011). Sponsorship portfolio as a brand-image creation strategy. Journal of Business Research, 64(2), 142-149.

Chipps, W. (2010). Sponsorship Spending Receded for the first time in 2009. Retrieved September 25, 2010, from http://www.sponsorship.com/About-IEG/.

Cornwell, T. B. \& Coote, L. V. (2005). Corporate sponsorship of a cause: the role of identification in purchase intent. Journal of Business Research, 58(3), 268-276. 
Cornwell, T. B., Humphreys, M. S., Maguire, A. M., Weeks, C. S., \& Tellegen, C. L. (2003). The Role of Articulation in Sponsorship-linked Marketing, Proceedings of the 2003 Advertising Conference, 5-7 June, Seoul, Korea, 8-9.

Cornwell, T. B. \& Maignan, I. (1998). An international review of sponsorship research. Journal of Advertising, 27(1), 1-27.

Crompton, J. (2004). Conceptualization and alternate operationalization of the measurement of sponsorship effectiveness in sport. Leisure Studies, 23(3), 267-281.

Dahl, D., Manchanda, R. V., \& Argo, J. J. (2001). Embarrassment, in consumer purchase, the roles of social presence and purchase familiarity. Journal of Consumer Research, 28(3), 473-481.

Daneshvary, R. and Schwer, R. K. (2002). The Association Endorsement and Consumers' Intention to Purchase. Journal of Consumer Marketing, 17(3), 203-213.

Dardis, F. E. (2009). Attenuating the Negative Effects of Perceived Incongruence in Sponsorship: How Message Repetition Can Enhance Evaluations of an Incongruent Sponsor. Journal of Promotion Management, 15(1-2), 36-56.

Ehrenberg, A. (1974). Repetitive advertising and the consumer. Journal of Advertising Research, 14(2), 25-34.

Fullerton, S. (2007). Sports Marketing. Boston: McGraw-Hill.

Grohs, R. \& Reisinger, H. (2005). Image transfer in sports sponsorships: an assessment of moderating effects. International Journal of Sports Marketing \& Sponsorship, 7(1), 42-48.

Grohs, R., Wagner, U., and Vsetecka, S. (2004). Assessing the effectiveness of sport sponsorships - an empirical examination. Schmalenbach Business Review, 56(2), 119-138.

Gwinner, K. (1997). A Model of Image Creation and Image Transfer in Event Sponsorship. International Marketing Review, 14(3), 145-158.

Gwinner, K. and Eaton, J. (1999). Building Brand Image Through Event Sponsorships: The Role of Image Transfer. Journal of Advertising, 28(4), 47-57.

Gwinner, K. and Swanson, S. R. (2003). A model of fan identification: antecedents and sponsorship outcomes. Journal of Services Marketing, 17(3), 275-294.

Hamlin, R. P. \& Wilson, T. (2004). The impact of cause branding on consumer reactions to products: Does product/cause 'fit' really matter? Journal of Marketing Management, 20(7-8), 663-681. 
Harris, T. (2000). In-Store Buying Habits Exposed. Professional Marketing, April/May, 25.

Hoek, J. \& Gendall, P. (2003). How does sponsorship work? Conference proceedings, Australia New Zealand Marketing Academy Conference, Adelaide, Australia.

Hoek, J., Gendall, P., \& Theed, K. (1999). Sports sponsorship evaluation: A behavioural analysis. International Journal of Sports Marketing and Management, 1(4), 328-344.

IEG (International Event Group). (2007). Sponsorship growth to increase for fifth straight year. Retrieved June 15, 2009, from http://www.sponsorship.com/About-IEG/.

Johar, G. V. \& Pham, M. T. (1999). Relatedness, Prominence and Constructive Sponsor Identification. Journal of Marketing Research, 36(3), 299-312.

Keller, K. L. (1993). Conceptualizing, Measuring, and Managing Customer-Based Brand Equity. Journal of Marketing, 57(January), 1-22.

Kline, R. B. (1998). Principles and practices of structural equation modelling. New York: Guilford.

Lacey, R., Sneath, J., Finney, Z., \& Close, A. (2007). The Impact of Repeat Attendance on Event Sponsorship Effects. Journal of Marketing Communications, 13(4), 243-255.

Lavidge, R. J. \& Steiner, G. A. (1961). A model of predictive measurements of advertising effectiveness. Journal of Marketing, 25(October), 59-62.

Lee, S. (2005). The influence of product involvement and fan identification on response to team sponsor's products. Unpublished thesis, Ohio State University, Columbus Ohio, U. S. A.

Little, T. D., Cunningham, W. A., Shahar, G., and Widaman, K. F. (2002). To parcel or not to parcel: Exploring the question, weighing the merits. Structural Equation Modeling, 9(2), 151-173.

Madrigal, R. (2000). The Influence of Social Alliances with Sports Teams on Intentions to Purchase Corporate Sponsors' Product. Journal of Advertising. 29(4), 455-469.

McDaniel, S. R. (1999). An Investigation of Match-Up Effects in Sport Sponsorship Advertising: The Implications of Consumer Advertising schemas. Psychology \& Marketing, 16(2), 163-184.

Meenaghan, A. (1983). Commercial sponsorship. European Journal of Marketing, 7(7), 5-73. 
Meenaghan, T. (2001). Understanding Sponsorship Effects. Psychology \& Marketing, 18(2), 95-122.

Munck, I. M. E. (1979). Model building in comparative education, Applications of the LISREL method to cross-national survey data International Association for the Evaluation Achievement Monograph Series Vol. 10, Almqvist \& Wiksell, Stockholm.

Nunnally, J. C. (1978). Psychometric Theory. (2nd ed.). New York: McGraw Hill.

Olson, E. L. and Thjømøe, H. M. (2003). The Effects of Peripheral Exposure to Information on Brand Performance. European Journal of Marketing, 37(1/2), 243-255.

Orth, U. R. and Malkewitz, K. (2006). Packaging design as resource for the constructions of brand identify, Conference Proceedings, $3^{\text {rd }}$ International Wine Business Marketing Conference, Montpelier, France.

Petty, R. E. and Cacioppo, J. T. (1986). Communication and Persuasion: Central and Peripheral Routes to Attitude Change, New York, NY: Springer-Verlag.

Pope, N. K. L. \& Voges, K. E. (1999). Sponsorship and image: a replication and extension. Journal of Marketing Communications, 5(1), 17-28.

Rifon, N. J., Choi, S. M., Trimble, C., \& Li, H. (2001). Consumer attributions of corporate sponsorship motive and the development of attitude toward the sponsor of health information on the World Wide Web, Conference proceedings American Academy of Advertising Conference, Salt Lake City.

Roper, S. and Parker, C. (2006). How (and where) the mighty have fallen: branded litter. Journal of Marketing Management, 22(5-6), 473-487.

Sen, S., Gurhan-Canli, Z., \& Morwitz, V. (2001). Withholding consumption: a social dilemma perspective on consumer boycotts. Journal of Consumer Research, 28(3), 399-417.

Sirgy, M. J., Lee, D. J., Johar, J. S., \& Tidwell, J. (2007). Effect of self-congruity with sponsorship on brand loyalty. Journal of Business Research, 61(10), 1091-1097.

Smith, A., Graetz, B., and Westerbeek, H. (2008). Sport sponsorship, team support and purchase intentions. Journal of Marketing Communications, 14(5), 387-404.

Speed, R. and Thompson, P. (2000). Determinants of Sports Sponsorship Response. Journal of the Academy of Marketing Science, 28(2), 226-238.

Summers, J., Gardiner, M., Lamb, C. W., Hair, J. F., and McDaniel, C. (2005). Essentials of Marketing. (2nd ed.). Australia: Nelson.

Tripodi, J. A. (2001). Sponsorship - a confirmed weapon in the promotional armoury. International Journal of Sports Marketing and Sponsorship, 3(1), 95-116. 
Underwood, R. L. (2003). The communicative power of product packaging: creating brand identify via lived and mediated experience. Journal of Marketing Theory and Practice, 11(1), 62-76.

Underwood, R. L. and Klein, N. M. (2002). Packaging as Brand Communication: Effects of Product Pictures on Consumer Responses to the Package and Brand. Journal of Marketing Theory and Practice, 10(4), 58-68.

Woods, J. and Walker, K. (2007). Choosing breakfast: How well does packet information on Australian breakfast cereals, bars and drinks reflect recommendations? Nutrition \& Dietetics, 64(4), 226-233.

Woodside, F. M. and Summers, J. (2011). Consumer Awareness of Sponsorship - a FMCG context. Journal of Marketing Communication, 17(2), 87-105.

Yong, J. K., Kyoungtae, K., Cathryn, L. C., and Tae Hee, K. (2008). The effects of sport involvement, sponsor awareness and corporate image on intention to purchase sponsors' products. International Journal of Sports Marketing \& Sponsorship, 9(2), 79-94. 